\title{
Impact of Service Quality dimension of Commercial Banks on Customer in Nepal
}

\author{
Ranu Maiya Shrestha \\ Lecturer, Nepal Commerce Campus, T.U.
}

\begin{abstract}
Commercial bank service quality dimensions and customer satisfaction are related with each other. Customer satisfaction play significant role for the success of bank. A structured questionnaire with 5 point Likert scale has been used to collect the data by conducting field survey. The sample size is 144 and chosen on a convenient basis. Data has been analyzed by using statistical tools like mean and Correlation Coefficient. The result revealed that service quality dimensions like such as tangibility, reliability, assurance, empathy, and responsiveness have significantly and positively correlated on customer satisfaction of commercial bank in Nepal.
\end{abstract}

Keywords: service quality, customer satisfaction, banks

\section{Background of the Study}

Wang et.al (2003) revealed that good quality have positive impact customer satisfaction for banking success in competitive market. Gautam and Dhital revealed expectancy disconfirmation paradigm, derived from social psychology for customer satisfaction. This research analyzed customer perception and expectation before using the product itself. Generally, customer satisfaction is highly dependent on outcome of perception, evaluation and psychological reactions to the consumption experience with a product or service. Dissanayake, Wasanth and Jinadasa (2016) analyzed the important of non -financial perspectives such as service performance, consumer behavioral responses in commercial banks.

Service quality dimension like tangibles, reliability, assurance, empathy, price factor and responsiveness have become the important factors to satisfy and retain loyal customers in service organization. Furthermore, service quality dimension have a significant impact on customer satisfaction in commercial banks of Nepal (Shrestha, 2018). Customer satisfaction is a satisfied feeling toward the service performance during consumption of service. (Caruana et al., 2002). Ramesh \& Kannan, (2011) analyzed that service quality attributes were positively correlated with customer satisfaction. Similarity, Prof Gopalkrishnan, et al, (2011) also revealed that Service quality and customer satisfaction have positively impacted on customer's retention as well customer loyalty.

Customer satisfaction is an important components to the every organizations existence. According to Nguli (2016), the consumer satisfaction is hard in measuring unless the factors are determined. Many factor either external or internal factors that together impact on the customer satisfaction in a bank. Internal factors are located within the banking sector and external factors are located outside the banking sector which effect on the customer's satisfaction. During the last 40 years, customer satisfaction has been taken as one of the importance theoretical and practical issues for marketers and customer researchers (Jamal, 2002). Narteh and Kuada, (2014) expressed that banks can only provide consumer satisfaction service, if standards, procedures, and policies for service quality exist in the business. Lovelock et al (2001) explained that customer satisfaction is an individual's feeling of pleasure or disappointment resulting from their 
expectations of service organization.

Singh and Kaur (2011) argued that customer satisfaction is depended on several factors like social responsibility, employee, responsiveness, tangibles, competence, and reliability, services innovation, positive word-of-mouth. Shrestha (2019) also argued that technology used in banks is also important for creating positive attitudes of customers. Furthermore, this study analyzed relationship marketing was influenced factor on increasing the customer satisfaction rate. Other factors like employee behavior, their friendliness, politeness, cooperation, promptness, efficiency, knowledge level, trustworthiness, and appearance also play significant role in determining the customer satisfaction.

\section{Statement of the Problem}

Now a day in Nepal, banking sectors are becoming more competitive than past and are found to be competing with each other due to increasing in numbers of banks. Thus, Banking sectors are paying more attention to the factors that satisfy the customer's desire and demand. Even though Nepalese banks may not be able to attracting new customers and retaining old customers. Banks need on maintaining customer satisfaction as well as achieving customer loyalty through delivering the quality services. Without delivering good quality services, business success may become impossible (Kristensen et al., 1992; McColl-Kennedy \& Schneider, 2000; Zeithaml et al., 1996). Thus, this research study explained the following questions:

- What are the service quality dimensions that effected on customer satisfaction of commercial banks in Nepal?

- What is the impact of service quality of banks in customer satisfaction in Nepal?

\section{Objective of the Study}

The objective of this study is to identify service quality dimension that influence on customer satisfaction of commercial banks in Nepal. The general objectives of this study are:

- To identify service quality dimensions on customer satisfaction of commercial banks in Nepal.

- To analysis the impact of service Quality of banks on customer satisfaction of commercial banks in Nepal.

\section{Literature Review}

Many researchers have analyzed the factors that influence on customer satisfaction in banking sectors time to time. The number of commercial banks has been increasing in Nepal due to the attractive market opportunity, especially after the democracy. But, commercial banks have issues in terms of customer satisfaction and their service quality. All the newly established commercial banks have tried to operate efficiently and effectively in Nepalese banking industry. However, Nepalese banking sector are facing the difficultly to grow and to maintain customer satisfaction as well as retention of customers.

Wilson et al. (2008) concluded that service quality is major factor in evaluation of customer's perception of reliability, assurance, responsiveness, empathy and tangibility while satisfaction is more inclusive and effected by perceptions of service quality. Besides that, situational factors and personal factors were also influenced on customer satisfaction. Sureshchander et al. (2002) analyzed that the relationship between service quality and customer satisfaction. This study explained the increased level of awareness among bank customers Demographic characteristics should be taken by the bank managers to understand their customers

Al-Khulaifi et al. (2000) resulted that employees' empathy, politeness and accuracy were the most important elements in customer satisfaction compared to other attributes in banking sectors.

Srivastav and Chatterjee (2008) revealed that five dimension of SERVQUAL scale effect on customer satisfaction. This study revealed that Responsiveness was the main criteria for customer satisfaction of SBI. Similarly, another study conducted by Bahzadi and Al-Hashash (2008) analyzed customer satisfaction in 
the retail banking in state of Kuwait. This study explained that bank's customers satisfaction and the reason for continuing their banking business were availability of ATM in several locations, phone account access, safety of funds, easy to use ATM, ease of opening a current account, bank image and reputation and the quality of services provided to them.

Dhital and Gautam (2004) explained that customers were more satisfied with second-generation joint-venture banks where customers were not needed to spend more time for their work and also the employee's attitudes were gentle. This study included the 331 customers' opinion from ten Nepalese commercial banks. Hence, NSBI and EBL apparently showed better performance in both the categories. Furthermore, customers were also found satisfied with HBL facilities offered like credit card, automatic teller machine etc. This study also fulfills some requirements of social audit of Nepalese commercial banks in terms of customer satisfaction as no such previous studies are conducted in context on Nepal.

The survey on bank's customer on the selected branch inside Kathmandu Valley of 28 Member Institution(s) of Nepal Bankers' Association was conducted by Bhatta (2010) in order to find out the behavior of the people regarding their financial activities. The results explained that young, educated, salaried, man from the eastern region of Nepal with high monthly income were the major consumer of banking services provided by the MI(s). Likewise, findings also shows that customers held a large amount of cash at hand, had transactions with more than one bank, and preferred the use of ATM or Debit-Cards rather than traditional instruments like Cheque. Further, the findings explained that customer focused on service quality and employees' behavior of their banks to be of utmost importance for choosing it, followed by technological innovations, number of branches and ATM available and other characteristics. Moreover, the enhancement of service quality and pleasant behavior from employees were suggested for customer retention as well as business increment in future.

Rahi (2015) concluded that customers loyalty were influenced by internet banking services as well as brand image of banks and help in maintaining relationship between banks and clients for enhancement of client loyalty toward banks. Furthermore, this study also explained that banks clients loyalty depend on facilitate provided by the banks.. Thus, brand image has positive and significant relationship between customers' loyalty and internet banking.

Akroush (2008) explained that service quality is the result of the comparison made by cunsumers about what consumers feel about service that offer by service organization, and perceptions of service providers the performance.

Munusamy et al. (2010) concluded on service quality delivery and its impact on customer satisfaction inm the Banking Sector Malaysian the banking sector, having quantitative research methodology. The result concluded that assurance, responsiveness, and empathy has positive relationship but it has no significant effect on customer satisfaction. Reliability has negative relationship but it has no significant effect on customer satisfaction. Tangibles have positive relationship and have significant impact on customer satisfaction.

Lopez et al. (2007) revealed that out of ten service quality dimension, six dimension like reliability, responsiveness, tangibles, access, communication, and credibility have shown the positive impact on customer satisfaction.

Al Tamimi and Al Amiri (2003) explained the five service quality dimensions between the two main Islamic banks of UAE, Abu Dhabi Islamic Bank and Dubai Islamic bank that. This study concluded that reliability was the most important service quality dimension among others. Thus, Service quality dimension were directly and positively impact on consumer satisfaction. Duff et al. (2008) explained the definition of service quality in companies and found result higher level of service quality directly impact on increased customer satisfaction.

\section{Research Methodology}

This study was used descriptive and inferential analysis as statistical tools for the analysis of the 
data collection. The survey method was used as structured questionnaire survey having 144 respondents of different commercial banks of Nepal. Each variable was measured using 5-points Likert scales such as 1= Strongly Agree, 2 = Agree, 3 =Neutral, 4 =Disagree, $5=$ Strongly Disagree. Percentage, mean, standard deviation is used for descriptive analysis and correlation as inferential analysis. Cronbach 's Alpha was used to test the internal consistency of response.

\section{Analysis and Findings}

\section{Descriptive Statistic Analysis}

Descriptive Statistic Analysis is performed for analyzing the collected data. The results are presented below:

Table 1

Descriptive Analysis of Service Quality Dimensions

\begin{tabular}{lc}
\hline Variables & Mean \\
\hline Assurance & 3.90 \\
Empathy & 3.39 \\
Reliability & 2.48 \\
Responsiveness & 3.15 \\
Tangibility & 4.21 \\
\hline
\end{tabular}

Source: Field survey

The above table 1 explained that tangibility of banks indicated the highest mean value 4.21 whereas reliability of bank indicated the lowest mean value 2.48 . Thus, this table analyzed that customers' satisfaction are highly influenced with reliability and less influenced tangibility in commercial banks of Nepal. Besides that, mean values of responsiveness, empathy and assurance are 3.15, 3.39, 3.90 respectively.

\section{Correlation Coefficient of Customer Satisfaction with service quality dimension}

The following table presents bivariate Pearson's correlation coefficient between different variables used in the study (customer satisfaction, tangibles, reliability, assurance, empathy and responsiveness. Correlation is significant at 1 percent level.

Table 2

Correlation Coefficient of Customer Satisfaction with service quality dimensions

\begin{tabular}{lllllll}
\hline & CS & EMP & REL & RES & ASS & RES \\
\hline CS & 1.000 & $.732^{*}$ & $.761^{*}$ & $.478^{*}$ & $.381^{*}$ & $.498^{*}$ \\
EMP & & 1.000 & $.301^{*}$ & $.126^{*}$ & $.213^{*}$ & $.162^{*}$ \\
REL & & 1.000 & $.268^{*}$ & $.207^{*}$ & $.055^{*}$ \\
RES & & & 1.000 & $.272^{*}$ & $.080^{*}$ \\
ASS & & & & & 1.000 & $.119^{*}$ \\
RES & & & & & & 1.000 \\
\hline
\end{tabular}

Source: Field Survey

The table 2 explained the correlation between dependent variables and independent variables in customer satisfaction with service quality dimension in commercial banks in Nepal. Customer satisfaction has significant and correlation relation service quality dimension of commercial banks in Nepal. All the independent variables have positive and significant correlation with customer satisfaction at $p$ value 0.05 . 
The correlation between customer satisfaction and reliability dimension was high $(0.761)$ and $\mathrm{p}$ value is 0.05 whereas assurance was low correlation $(0.381)$

\section{Conclusion}

This study explained that there is a positive significant relationship between service quality dimension and customer satisfaction in commercial banks of Nepal. Among the service quality dimension, reliability is highly correlated with customer satisfaction in commercial bank in Nepal. Therefore, the bank should be able to satisfy the customers through superior services and facilities. The bank must try to maintain long term relationship with customers. The customers must believe that their respective banks deliver what they promise in their advertisement. Thus the bank should regularly take the feedback of the customers. Service quality dimension play significant role to satisfy their customers in commercial banks.

\section{References}

Akroush, M.N. (2008) Exploring the mediating effect of service quality implementation on the relationship between service quality and performance in the banking industry in Jordan, Global Business and Economics Review, 10(1), 98-122.

Al-Tamimi, H.A. and Al-Amiri, A. (2003). Analyzing service quality in the UAE Islamic banks. Journal of Financial Service Marketing, 8(2), 119-32.

Asia Pacific Perspective, 2nd Ed. Australia: Prentice Hall.

Bhatta. K. P. (2010). Customer Behavior and Preferences: A survey Report. Banking Journal, $1(1), 63-74$.

Bloemer, J. (1998). Investigating derivers of bank loyalty: the complex relationship between image, service quality and satisfaction. International Journal of Bank Marketing, 16(7), 276-286.

Duff, A., Guo, X. and Hair, M. (2008) Service quality measurement in the Chinese corporate banking market, International Journal of Bank Marketing, 26(5), 305 - 327.

Gupta, A., \& Dev, S. (2012). Client satisfaction in Indian banks: An empirical 0020study. Management Research Review, 35(7), 617-636.

Jamal, A \& Naser, K. (2002). Customer satisfaction and retail banking: An assessment of some of the key antecedents of customer satisfaction in retail banking. International Journal of Bank Marketing, 20(4), 146-160.

Kotler, P. (2006). The Importance of Customer Satisfaction in Relation to Customer Loyalty and Retention. UTCI Working Paper WP-06-06.

Kotler, P., and Armstrong, G. (2010) Principles of Marketing (13th ed.), Pearson Education, London

Kundu, S., \& Datta, S. K. (2015). Impact of trust on the relationship of e-service quality and customer satisfaction. EuroMed Journal of Business, 10(1), 21-46.

Lopez, J.; Kozloski Hart, L \& Rampersad, A. (2007). Ethnicity and customer satisfaction in the financial services sector. Managing Service Quality: An International Journal, 17(3), 259-274.

Lovelock, C. H., Patterson, P. G., and Walker, R. H. (2001): Services Marketing: An

Narteh, B., \& Kuada, J. (2014). Customer Satisfaction with Retail Banking Services in Ghana. Thunderbird International Business Review, 56, 353-371. http://dx.doi.org/10.1002/tie.21626

Nguli, R. K. (2016). Internal Factors Affecting Customer Satisfaction of Commercial Banks in Kitui Town. Kitui Town.

Saghier, N. E., and Nathan, D. (2013). Service quality dimensions and customers' satisfactions of banks in Egypt. International Business Research Conference.

Shrestha, P. (2018). Service quality and customer satisfaction: Evidence of Nepalese banks. NCC Journal, 3(1), 121-133. https://doi.org/10.3126/nccj.v3i1.20254

Shrestha, P. (2019). Banking customer attitudes toward ATM service in Nepal. International Journal of Advances in Scientific Research and Engineering, 5(12), 88-93. DOI: 10.31695/IJASRE.2019.33652 
Sureshchandar, G. (2002). Determinants of customer perceived service quality: a confirmatory factor analysis approach, Journal of Services Marketing, 16(1), 9-34.

Wilson, A., Zeithaml, V., Binter, M. and Gremler, D. (2008). Service Marketing: Integrating Customer Focus across the Firm, McGraw-Hill, and London.

Zeithaml, V.A., \& Bitner M. J. (2000). Services Marketing (2nd ed.). New York : McGrawHill. Inc.

Zeithmal V. And Bitner, M. (2004) Service Marketing 7 west patal Nagar, New Delhi. 